2016

\title{
The Jonas Short Site (41SA101), San Augustine County, Texas
}

Timothy K. Perttula

Heritage Research Center, Stephen F. Austin State University

Mark Walters

Heritage Research Center, Stephen F. Austin State University

Follow this and additional works at: https://scholarworks.sfasu.edu/ita

Part of the American Material Culture Commons, Archaeological Anthropology Commons, Environmental Studies Commons, Other American Studies Commons, Other Arts and Humanities Commons, Other History of Art, Architecture, and Archaeology Commons, and the United States History Commons

Tell us how this article helped you.

This Article is brought to you for free and open access by the Center for Regional Heritage Research at SFA ScholarWorks. It has been accepted for inclusion in Index of Texas Archaeology: Open Access Gray Literature from the Lone Star State by an authorized editor of SFA ScholarWorks. For more information, please contact cdsscholarworks@sfasu.edu. 


\section{The Jonas Short Site (41SA101), San Augustine County, Texas \\ Creative Commons License \\ (c) $)(1)$ (9)}

This work is licensed under a Creative Commons Attribution-NonCommercial 4.0 International License 


\title{
The Jonas Short Site (41SA101), San Augustine County, Texas
}

\author{
Timothy K. Perttula and Mark Walters
}

\section{INTRODUCTION}

The Jonas Short site (41SA101) is one of a few known and investigated Woodland period mounds in the Trans-Mississippi south (i.e., East Texas, Northwest Louisiana, Southwest Arkansas, and Southeast Oklahoma) (Schambach 1982, 1998, 2002; Girard 2012:Figure 11). In fact, the site is one of only four identified mound sites of possible Woodland period age - and Mossy Grove cultural tradition - in the Neches-Angelina and Sabine river basins in East Texas and Northwest Louisiana: Coral Snake (16SA48), Anthony (16SA7), Jonas Short, and Westerman (41HO15) ${ }^{1}$ (Story 1990:279 and Figure 41) (see Foreword, Figure 1).

The Jonas Short site was located on an alluvial terrace of the Angelina River. It was investigated in 1956 by archaeologists from the University of Texas and the River Basin Survey prior to its inundation by the waters of Lake Sam Rayburn (Jelks 1965:22-52; see also McClurkan et al. 1980; Story 1990:280, 282).

\section{Excavations}

The excavations at the Jonas Short site focused on a small earthen mound about $29 \mathrm{~m}$ in diameter and $2.4 \mathrm{~m}$ in height (Figure 1). Surrounding the mound was a borrow pit about $1.2 \mathrm{~m}$ in depth and $4.6 \mathrm{~m}$ in width. In the mound was a cremation under the center of the mound and five caches of artifacts in the southwestern quadrant of the mound excavations, but in Zone A or Zone B mound fill. Zone A (ca. $1.8 \mathrm{~m}$ thick) was the basal mound deposit of light gray sand, and Zone B was an overlying and compact red sandy clay; "there was no evidence of a significant time interval between the two" (Story 1990:280).

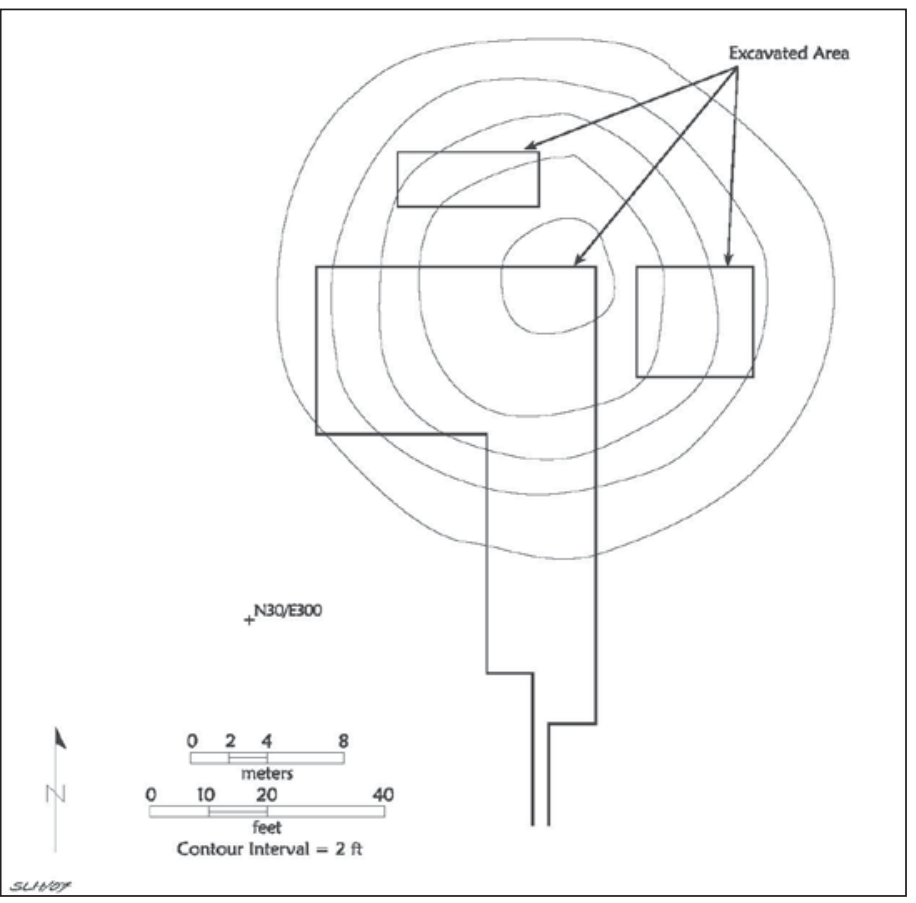

Figure 1. Excavation area in the mound at the Jonas Short site. 
The cremation (Burial 2) contained at least two individuals (based on human teeth from different individuals) that were burned in situ, in an $0.6 \times 1.8 \mathrm{~m}$ area of burned human bone, charcoal, and other burned organic materials (Jelks 1965:30). Found with this burial were two copper bracelets. Apparently immediately after the cremation event, the burial feature was covered by the light gray sand Zone A mound fill. Story (1990:280) suggested that "the death of one or both of the cremated individuals appear to have been the event that triggered the building of the mound." After the deposition of Zone A mound fill, the mound was capped with Zone B reddish sandy clay.

The caches of artifacts were placed in the mound fill as the mound was being constructed and built up, and there was no evidence recorded during the excavations that suggested these caches were placed in pits (Jelks 1965:35, 43; Story 1990:280). Only a single human skull fragment was found in one of the caches (Cache 2), but in the case of the other four caches, the "possibility that they had completely decomposed, leaving no trace [of human remains], cannot be discounted" (Story 1990:280).

Cache 1 (in Zone B) had a boat stone made from a non-local igneous raw material, a quartz pendant (Jelks 1965:Figure 14b), and nine quartz crystals. There were a number of small stream-rolled quartz pebbles inside the boat stone concavity. Jelks (1965:37) suggested that the quartz pendant and the quartz crystals were "part of a single necklace or similar ornament."

Cache 2 (in Zone B) had a number of unique offerings. Among them were a large oval biface made from non-local chert, a well-made Gary dart point (Jelks 1965:Figure 17h) of petrified wood, four large stemmed dart points, a reel-shaped copper gorget, at least 11 perforated elk teeth, and a small piece of a probable human skull. The copper gorget and elk teeth were apparently strung on a necklace, perhaps along with two of the large stemmed dart points, based on their position in the cache (Jelks 1965:40).

Cache 3 was found in the upper part of the Zone A mound fill. This cache had a hornblende syenite boat stone (Jelks 1965:Figure 13d), petrified wood knife fragments, a concentration of stone chips, and a few pieces of unidentifiable bone (Jelks 1965:42).

Cache 4 covered an area $0.4 \times 0.2 \mathrm{~m}$ in size in the upper part of Zone A. Found in it were "a small heap of water-worn pebbles," lithic debris, and one petrified wood Kent dart point (Jelks 1965:43 and Figure 13e).

The last cache, Cache 5, was also encountered in the upper part of Zone A in the mound. Artifacts in the cache covered a $1.8 \mathrm{~m}$ area, and included 61 small stream-worn pebbles, eight petrified wood chips, a quartz crystal with a grooved end, and two Kent dart points made of petrified wood (Jelks 1965:44 and Figure $13 \mathrm{f}-\mathrm{g})$.

\section{Funerary Offerings}

\section{Copper Bracelets}

The bracelets are from Burial 2, the pre-mound cremation that was buried by mound fill. The bracelets are part of multiple bracelet elements stacked one atop another. These bracelets are the sole funerary offerings from Burial 2.

The bracelets were made from strips or bars of copper between 1.9-3.9 mm thick that were bent into a rough circular shape (Figure 2 and Table 1). They each have relatively small gaps between the two ends of each bracelet. The compound bracelet (Figure 2a, c-d) "consists of four separate elements - each made of a copper bar that is square to subrectangular in cross section-stacked on top of one another. The bars were bent into individual bracelets" (Jelks 1965:31). 


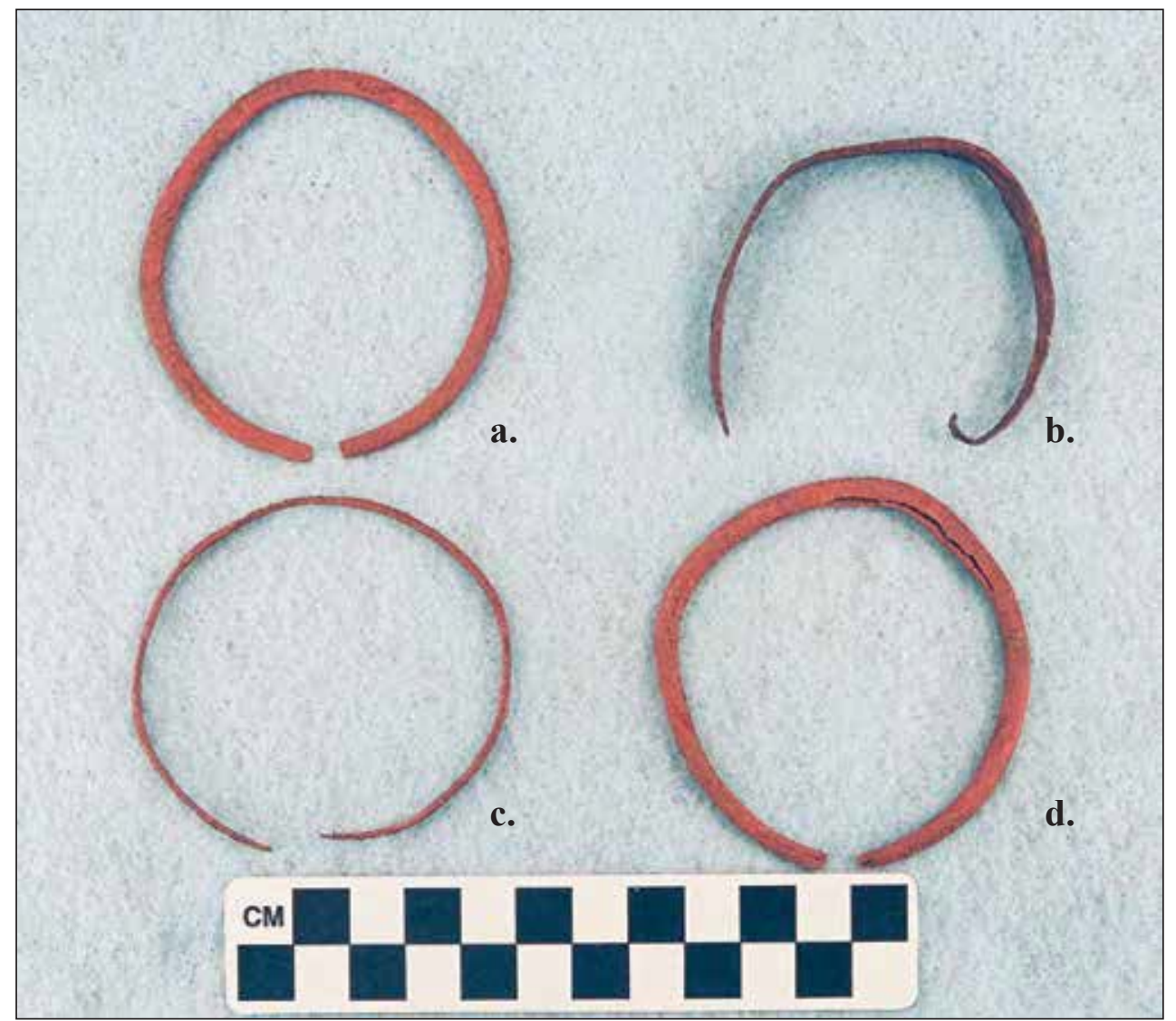

Figure 2. Copper bracelets from Burial 2 at the Jonas Short site: a, c-d, elements of the second bracelet; $b$, first bracelet.

Table 1. Copper bracelets from the Jonas Short site.

\begin{tabular}{llcl}
\hline $\begin{array}{l}\text { Diameter } \\
(\mathrm{mm})\end{array}$ & $\begin{array}{l}\text { Bracelet opening } \\
(\mathrm{mm})\end{array}$ & $\begin{array}{r}\text { width of the bracelet band } \\
(\mathrm{mm})\end{array}$ & $\begin{array}{l}\text { Thickness } \\
(\mathrm{mm})\end{array}$ \\
\hline 69.0 & 5.0 & 3.7 & 3.6 \\
70.0 & 5.0 & 4.1 & 3.9 \\
63.0 & 9.0 & 3.4 & 1.9 \\
36.0 & $39.0^{*}$ & 11.0 & 2.4 \\
\hline
\end{tabular}

* as originally measured by Jelks (1965:31), the gap between the two ends of the bracelet was $16.0 \mathrm{~mm}$.

\section{Thin Hammered Copper Fragments}

There are a number of miscellaneous small fragments of thin hammered sheet copper from Cache 2 (Figure 3). These small pieces are apparently all that are left of the reel-shaped copper gorget (Jelks 1965:Figure 17b) found in this cache along with a large biface, a Gary point, four large stemmed dart points, and perforated elk teeth. One of the pieces of copper has small rivets $(2.5 \mathrm{~mm}$ in diameter $)$ visible in it. 


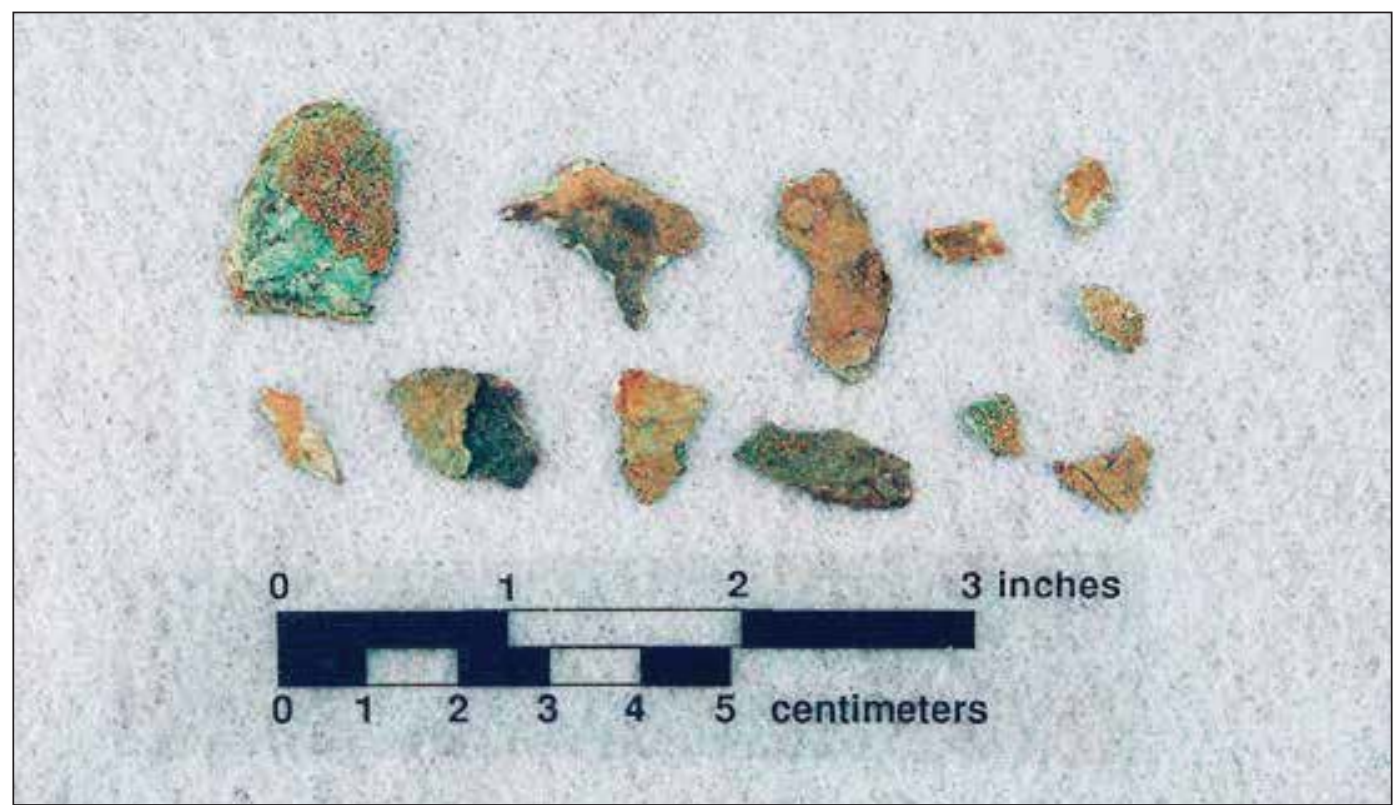

Figure 3. Fragments of thin hammered copper fragments from Cache 2 at the Jonas Short site.

\section{Perforated Elk Teeth}

The 11 perforated elk teeth (Figure 4) are also from Cache 2; they are copper-stained, presumably because they came in contact with the copper gorget found in this cache. The elk teeth have 1.1-3.1 mm perforations. The elk teeth are not all of the same form, suggesting they received some modification at the time they were perforated. The smaller elk teeth $(n=2$, with the smaller perforations) are narrow in width, with another seven rectangular in shape with larger perforations near the top of the tooth. Two other perforated elk teeth are fragmentary.

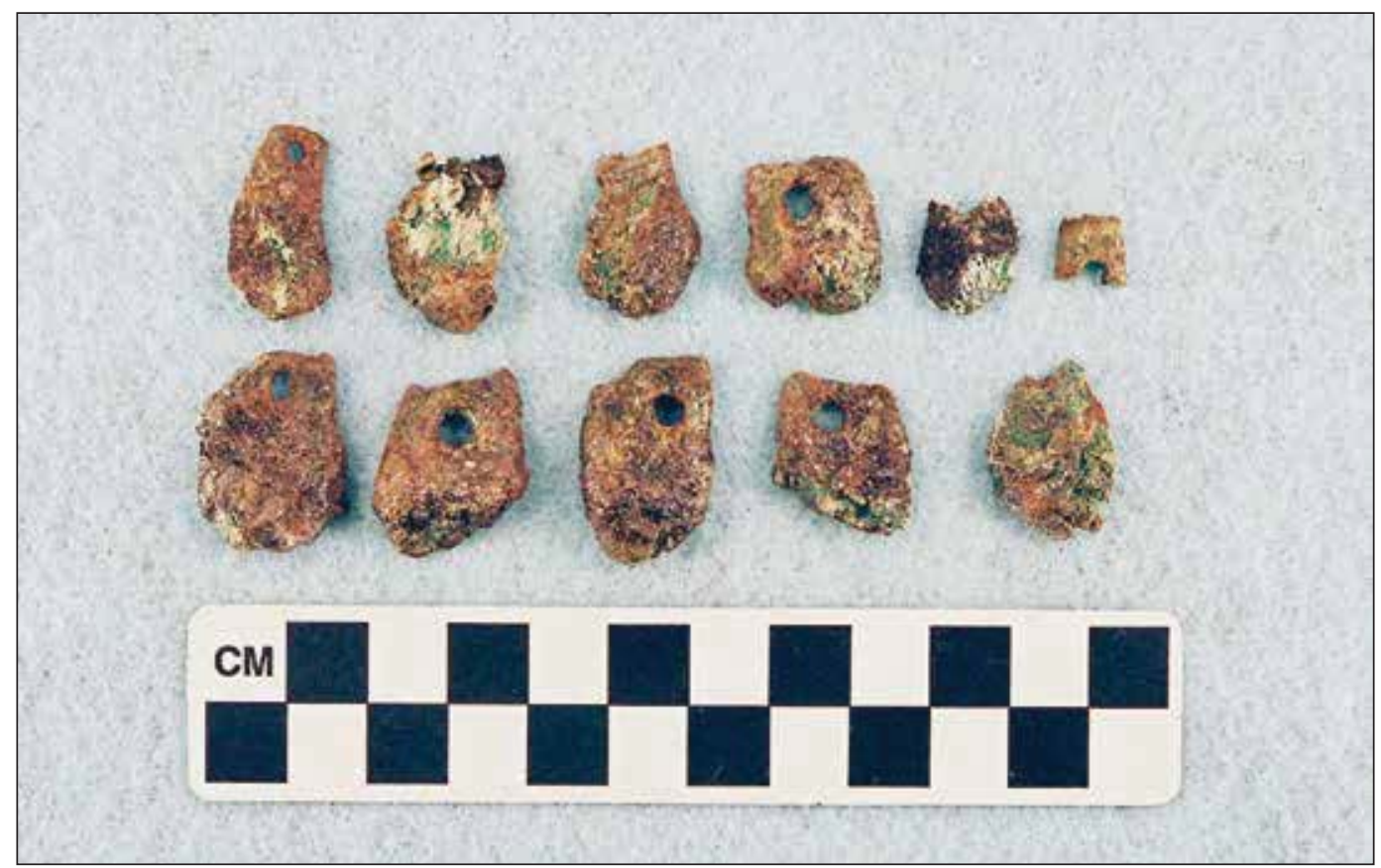

Figure 4. Perforated elk teeth from Cache 2. 


\section{Large Dart Point}

The one remaining very large stemmed dart point in the collections from the Jonas Short mound excavations is also from Cache 2 (Figure 5; see also Jelks 1965:Figure 17d). It was found about 0.8 m northeast of the copper gorget.

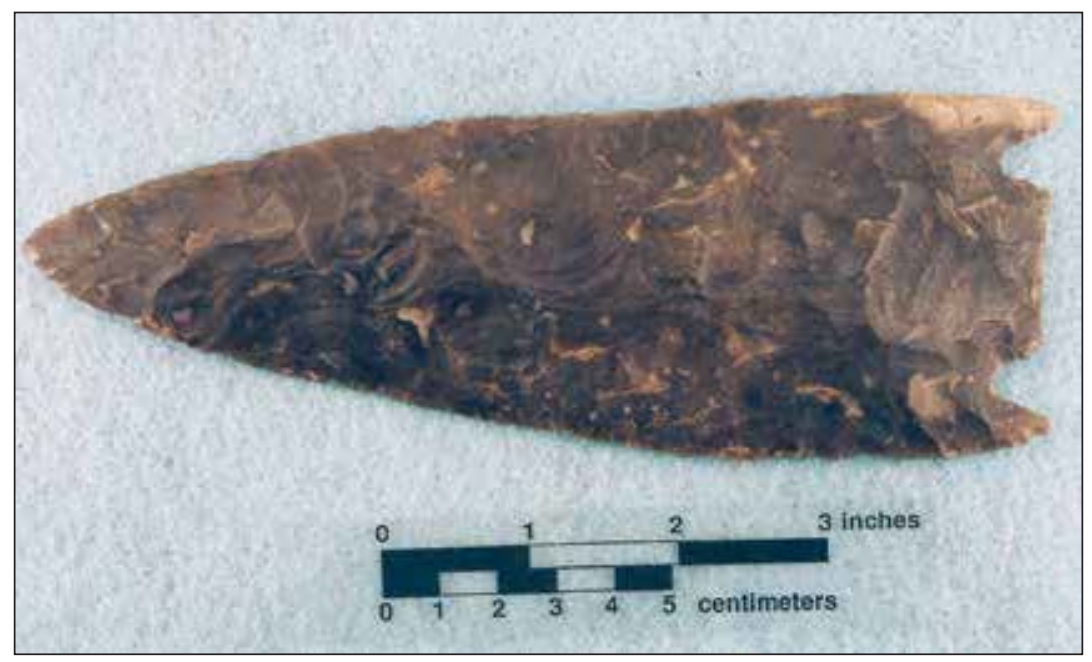

Figure 5. Large dart point from Cache 2 at the Jonas Short site.

The point has a slightly contracting and short stem, a flat base, and downward-pointing barbs shaped by basal notching on the stem. It is $17.2 \mathrm{~cm}$ in length, a maximum of $6.2 \mathrm{~cm}$ in width, $12.8 \mathrm{~mm}$ in thickness, and has a stem width of $3.1 \mathrm{~cm}$.

The large dart point is made of a lustrous dark grayish-brown chert of non-local origin, probably Edwards Formation chert; there is no cortex remaining on the tool. The appearance of the chert and fossil inclusions compare favorably to Georgetown chert in the Colorado River basin in Central Texas (Bob D. Skiles, April 25, 2015 personal communication). Both edges of the dart point have been serrated by fine pressure flaking.

\section{Biface}

Also found in Cache 2 was a very large oval-shaped biface (Figure 6; see also Jelks 1965:Figure 17a) or bifacial blank. It is $16.6 \mathrm{~cm}$ in length, a maximum of $9.84 \mathrm{~cm}$ in width, and $23.0 \mathrm{~mm}$ in thickness.

The biface is made from a lustrous dark gray to a dark blackish-gray chert, and all evidence of cortex has been removed by hard hammer shaping and thinning flakes. There is evidence of platform abrading and crushing on both lateral edges of the biface, but otherwise the edges are sinuous and still sharp. The source of the chert is not known with certainty, but the size of the biface and the chert's lustrous quality indicate that it is not of local origin, because any local cherts are at best pebble-sized and have earth-toned colors, and likely is also Georgetown chert.

\section{Boat stone}

Cache 1 had a polished boat stone, found in two pieces, made from hornblende syenite (Jelks 1965:36 and Figure 13c-c') from the Hot Springs, Arkansas, area of the Ouachita Mountains. This specific mineral has an abundance of distinctive outcrops of igneous rocks that are not found elsewhere over a considerable area of Texas, Louisiana, and surrounding states (Rolingson and Howard 1997:34-35). 


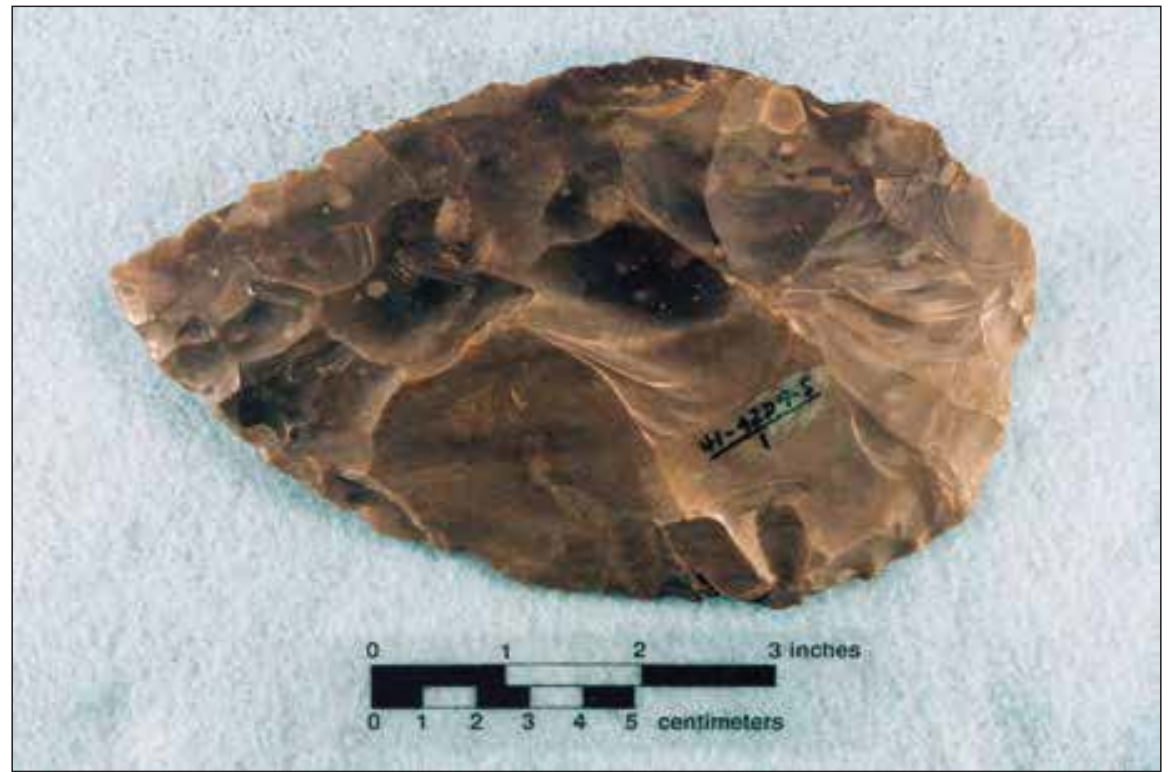

Figure 6. Biface from Cache 2 at the Jonas Short site.

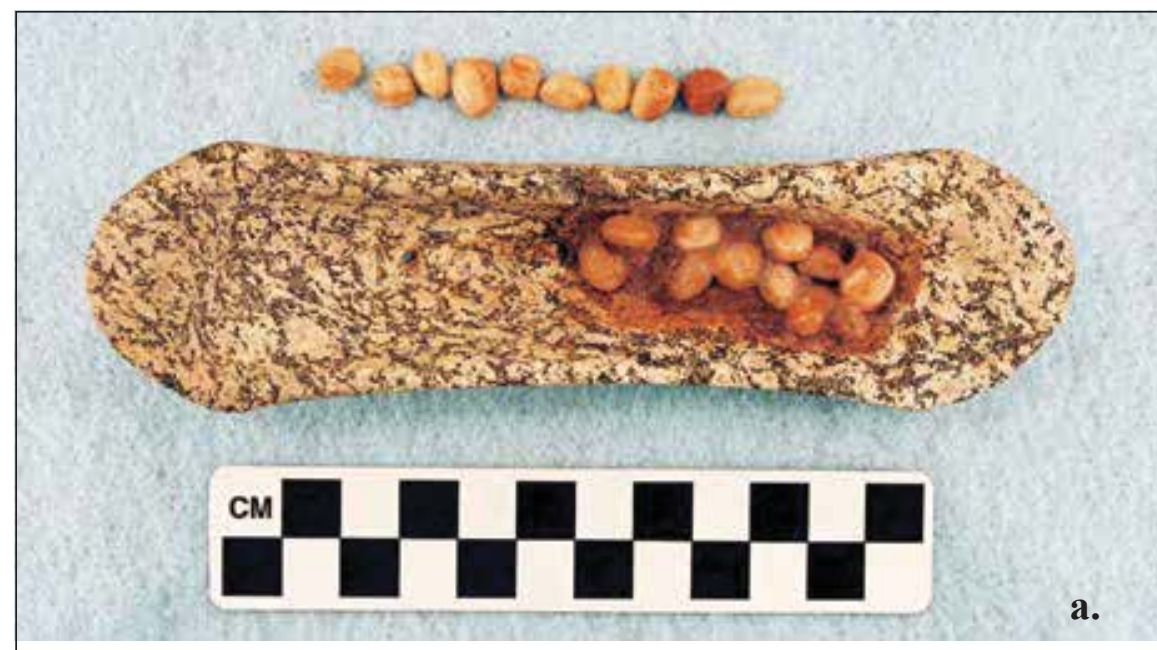

Figure 7. Cache 1 boat stone: a, interior concavity and stream-rolled quartz pebbles; $b$, exterior surface of the boat stone.

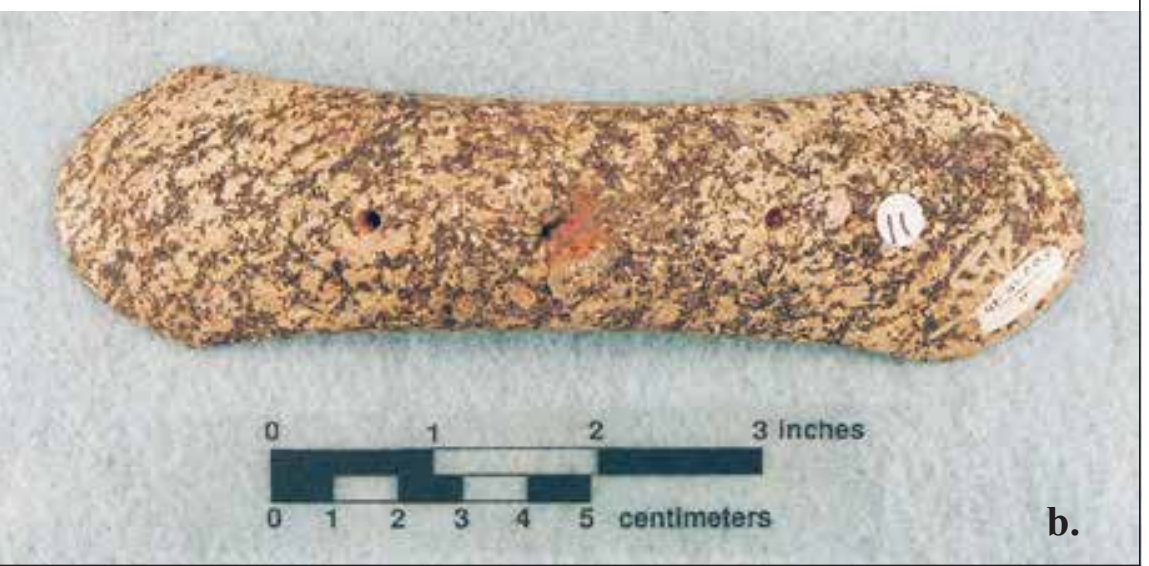


The boat stone had 21 small stream-rolled quartz pebbles that were found in the interior and hollowed out cavity of the tool (Figure 7a). These pebbles may have been collected from Red River gravels either well north or east (Thomas et al. 1980:208) of the Jonas short site.

Two small holes ( $3.2 \mathrm{~mm}$ in diameter) had also been drilled through the boat stone, beginning from the exterior tool surface (see Figure 7b). The boat stone is $15.3 \mathrm{~cm}$ in length, 3.4-4.3 cm in width (measured across the center and one end of the tool), and had a height of $2.61 \mathrm{~cm}$ along its crest.

\section{Quartz Crystals}

There are 10 quartz crystals in the Jonas Short site collection, nine from Cache 1 and the other from Cache 5 (Figure 8). A quartz pendant was among the artifacts found in Cache 1 (Jelks 1965:Figure 14b), but it is not currently in the TARL collections. Such large quartz crystals or quartz pieces for making pendants would not have been available locally, but certainly such materials could have been obtained from sources in the Ouachita Mountains of southeastern Oklahoma and southwestern Arkansas.

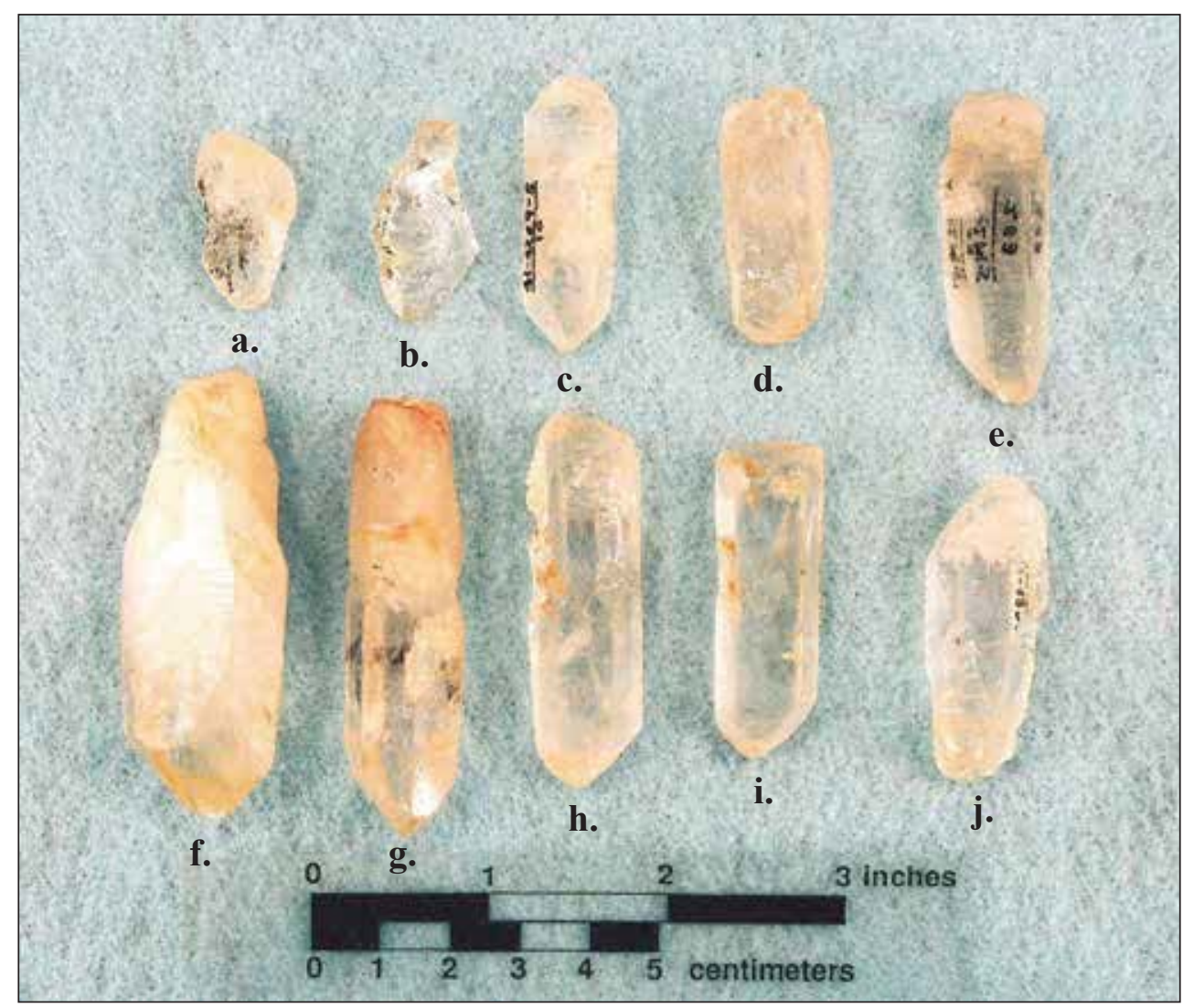

Figure 8. Quartz crystals from the Jonas Short mound excavations, Caches 1 and 5: a-c, $\mathrm{e}-\mathrm{j}$, Cache 1; d, Cache 5.

Three of the quartz crystals, all from Cache 1 (see Figure 8c, e-f), have shallow grooved or faceted tips (Table 2). Jelks (1965:37) suggested that this working of one end of the crystal was designed for their suspension on a necklace. 
Table 2. Quartz crystals from the Jonas Short site.

\begin{tabular}{|c|c|c|c|c|c|}
\hline Lot No. & $\begin{array}{l}\mathrm{L} \\
(\mathrm{mm})\end{array}$ & $\begin{array}{l}\mathrm{W} \\
(\mathrm{mm})\end{array}$ & $\begin{array}{l}\text { Th } \\
(\mathrm{mm})\end{array}$ & No. of Facets & Comments \\
\hline \multicolumn{6}{|c|}{ Crystals with faceted or grooved tips } \\
\hline 12 & 43.8 & 16.2 & 13.6 & 6 & - \\
\hline 15 & 25.0 & 11.2 & 10.2 & - & crushed facets; cloudy quartz \\
\hline 16 & 38.2 & 12.9 & 9.7 & 6 & clear quartz \\
\hline \multicolumn{6}{|c|}{ Crystals with unfaceted tips } \\
\hline 7 & 44.2 & 14.0 & 9.7 & 6 & clear quartz \\
\hline 8 & 60.0 & 17.9 & 14.0 & 6 & clear-cloudy quartz \\
\hline 13 & 62.0 & 20.2 & 19.6 & 6 & clear-cloudy quartz \\
\hline 14 & 53.2 & 13.9 & 12.9 & 6 & clear quartz \\
\hline 17 & 28.9 & 14.9 & 11.0 & - & $\begin{array}{l}\text { flake fragment with crushed } \\
\text { end; clear quartz }\end{array}$ \\
\hline 40 & 36.0 & 17.8 & 14.7 & 6 & clear quartz \\
\hline 263 & 44.3 & 13.9 & 10.7 & 5 & clear quartz \\
\hline
\end{tabular}

The quartz crystals have between five and six facets, and they have been stream-worn. Most of the crystals are a clear quartz, but three have a cloudy or smoky appearance.

The use of quartz crystals and quartz ornaments has been attested to in ancestral Caddo burials in a number of sites in northeastern Texas, southwestern Arkansas, and northwestern Louisiana (Perttula et al. 1998:324, 326). Their use as funerary offerings was also important in Woodland period contexts, as shown by the quartz pendant and crystals from Cache 1 and 5 at Jonas Short and the polished quartz figurine from the Coral Snake mound site (16SA48) in northwestern Louisiana (McClurkan et al. 1966:Figure 14j, 1980:Figure 9j).

Quartz crystals and other artifacts made from quartz may have been a source of power for the Woodland period individuals or groups that possessed them (and then had them buried) at the Jonas Short site, just as they were for other Southeastern U.S. Native American groups (see Hudson 1976:168, 356-357). Hudson (1976:356-357) has noted that quartz crystals were aids in hunting and in predicting the future, and "had to be handled carefully. They were hidden in a dry place until they were actually used, and they were never kept inside one's house." Emerson (1989:82) commented that because quartz crystals were considered "underworld" objects, they gave the owners power, but a power that had to be carefully controlled by caring for the crystal: "When the owner died it [the quartz crystal] was buried with him or else it would roam free, seeking the lives of men."

There are artifacts from non-mound contexts at the Jonas Short site, including a few sherds collected by Gus Arnold in 1940 during the Works Progress Administration survey of East Texas (Site ET-779), as well as a larger assemblage collected by Stephenson (1948) during the archaeological survey of proposed McGee Bend Reservoir/Lake Sam Rayburn. The collected artifacts are primarily ceramic vessel sherds $(n=168)$ and two chipped stone tools.

There are 164 grog- and bone-tempered Caddo vessel sherds in the analyzed TARL collections. The grog-tempered sherds represent 55 percent of the sherds, and the remainder are bone-tempered (Table 3 ). 
Table 3. Ceramic sherds from ancestral Caddo vessels from archaeological survey investigations at the Jonas Short site (41SA101).

\begin{tabular}{|c|c|c|c|}
\hline \multirow[t]{2}{*}{ Wares } & \multicolumn{2}{|c|}{ Temper } & \multirow[t]{2}{*}{$\mathrm{N}$} \\
\hline & grog & bone & \\
\hline Plain & 76 & 58 & 134 \\
\hline Utility & 14 & 14 & 28 \\
\hline Fine & 1 & 1 & 2 \\
\hline Totals & 91 & 73 & 164 \\
\hline
\end{tabular}

More than 93 percent of the decorated sherds in the survey assemblage are from utility ware vessels (Table 4). About 54 percent of the decorated sherds are from vessels with parallel (i.e., most likely with a vertical orientation on the vessel body) brushing marks. The high proportion of brushed sherds in the assemblage indicate that the Caddo occupation at the site took place in post-A.D. 1400 Caddo times. The sherds with incised decorative elements $(n=10,35.7$ percent of the utility wares) have horizontal and geometric lines, including one sherd with a vertical incised line and attached diagonal lines (Figure 9a); this sherd may be from a Pease Brushed-Incised vessel (see Suhm and Jelks 1962:Plate 60k). The punctated sherds have either tool or circular punctated rows around the vessel.

Table 4. Decorative methods and elements on the ancestral Caddo vessel sherds from the Jonas Short site.

\begin{tabular}{llll}
\hline Decorative method/ & Rim & Body & N
\end{tabular}

decorative element

Utility Ware

Brushed

parallel brushing marks

Incised

horizontal line under the lip

opposed lines

parallel lines

straight line

vertical lines

vertical and diagonal lines

$\begin{array}{lll}1 & - & 1 \\ - & 1 & 1 \\ - & 3 & 3 \\ - & 2 & 2 \\ - & 1 & 1 \\ - & 1 & 1\end{array}$

\section{Punctated}

circular punctated row

tool punctated row

\begin{tabular}{lll}
- & 2 & 2 \\
- & 2 & 2 \\
& \\
- & 1 & \\
- & 1 & - \\
1 & 29 & - \\
\hline
\end{tabular}

\section{Fine Ware}

Engraved

curvilinear cross-hatched zone

diagonal excised zone

Totals

(20)




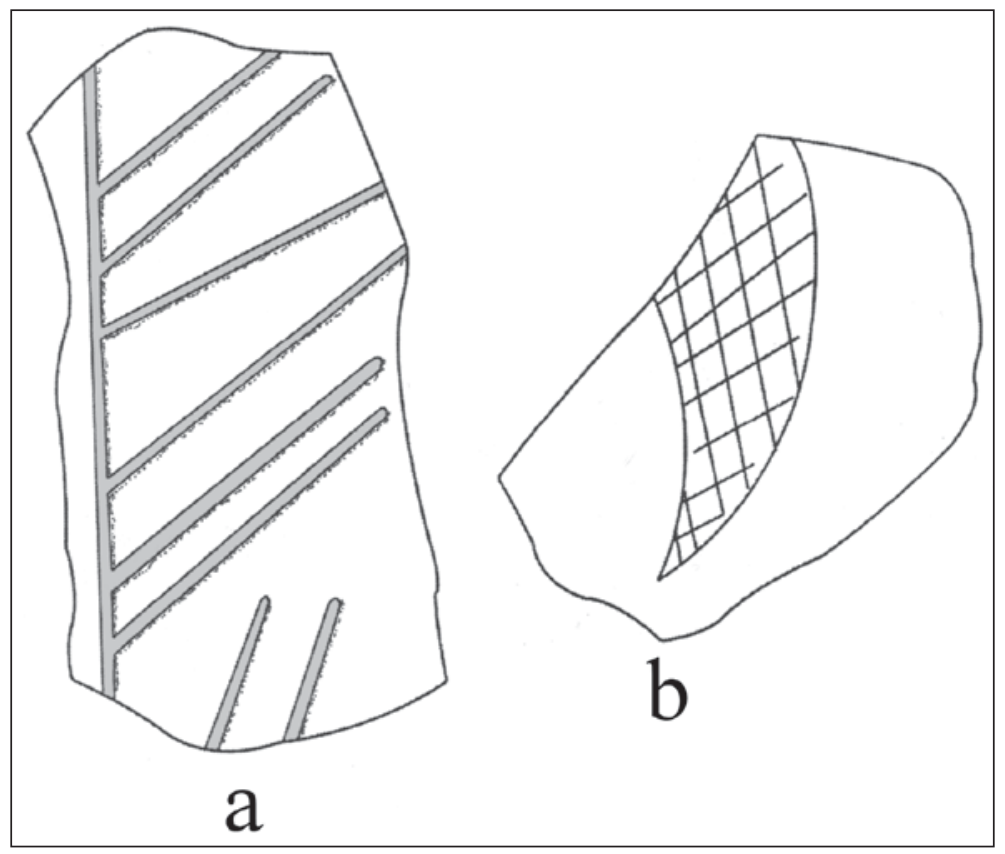

Figure 9. Selected decorative elements on utility ware and fine ware sherds from the Jonas Short site: a, vertical and diagonal incised body sherd; $b$, curvilinear cross-hatched zone body sherd.

One of the engraved fine ware sherds is from a carinated bowl. It has a diagonal excised zone on the rim panel. The other engraved sherd is a body sherd with a curvilinear zone filled with cross-hatched lines (see Figure 9b).

There are also four Goose Creek Plain, var. unspecified body sherds in the ceramic assemblage examined at TARL. According to Story (1990:Table 65), another 102 sandy paste sherds (including two decorated sandy paste sherds) were recovered from the surface or disturbed areas ( $\mathrm{n}=93)$, as well as in the mound fill $(n=9)$. These are part of the Woodland period occupation of the Jonas Short site.

The lithic artifacts from the site were both collected by Stephenson. They include a tan chert arrow point preform and a petrified wood Friley arrow point.

\section{SUMMARY AND CONCLUSIONS}

The Jonas Short mound site on the Angelina River basin is an undated Woodland period mound with a cremation (with evidence of multiple individuals) under the center of the mound and a number of caches/ funerary offerings in Zone A and B mound fill deposits. The caches/funerary offerings include copper bracelets, a copper gorget, copper-covered elk teeth, large dart points and a bifacial blank, a hornblende syenite boatstone, a quartz pendant, and 10 large quartz crystals. These caches/funerary offerings may represent prestige goods (cf. Schambach 2002:110-112): placed with the cremated burials. Radiocarbon dates from other comparable Middle Woodland period mounds in the region range from 1650-1970 B.P. from the Coral Snake mound site (16SA48) (Story 1990:Table 67), to $1950 \pm 40$ B.P. from the Phelps Lake mound (16BO24), $2190 \pm 120$ B.P. from the McKinney Mound (16CD52), and $2200 \pm 70$ B.P. from the Jim Burt Mound (16BO23) (Girard 2012:69-70), and these dates suggest that the construction and use of the mound at the Jonas Short site was contemporaneous with these Northwest Louisiana Woodland period mound sites. 
Grog- and bone-tempered Caddo ceramic sherds from mainly non-mound contexts indicate that the Jonas Short site was also occupied by Caddo peoples. The high proportion (50 percent) of brushed sherds in the decorated sherd assemblage indicate that the Caddo occupation at the site took place in post-A.D. 1400 times.

\section{NOTES}

1. The Westerman site $(41 \mathrm{HO} 15)$ has one small $(20 \times 25 \mathrm{~m})$ earthen mound. Recovered artifacts from the surface and in a pothole in the mound suggest that the mound was actually built and used during the Early Caddo period (Perttula 2015:104).

\section{ACKNOWLEDGMENTS}

The photographs in this article were taken by Bo Nelson during NAGPRA documentation (Perttula et al. 2009). Other figures were prepared by Sandra Hannum and Lance Trask.

\section{REFERENCES CITED}

Emerson, T. E.

1989 Water, Serpents, and the Underworld: An Exploration into Cahokian Symbolism. In The Southeastern Ceremonial Complex: Artifacts and Analysis, The Cottonlandia Conference, edited by P. Galloway, pp. 45-92. University of Nebraska Press, Lincoln.

Girard, J. S.

2012 The Bellevue Site (16BO4): A Middle Woodland Period Mound in Northwest Louisiana. Louisiana Archaeology 35:53-77.

Hudson, C.

1976 The Southeastern Indians. The University of Tennessee Press, Knoxville.

Jelks, E. B.

1965 The Archeology of McGee Bend Reservoir, Texas. Ph.D. dissertation, Department of Anthropology, The University of Texas at Austin.

McClurkan, B. B., W. T. Field, and J. N. Woodall

1966 Excavations in Toledo Bend Reservoir, 1964-65. Papers of the Texas Archeological Salvage Project No. 8. Texas Archeological Salvage Project, The University of Texas at Austin.

McClurkan, B. B., E. B. Jelks, and H. P. Jensen

1980 Jonas Short and Coral Snake Mounds: A Comparison. In "Caddoan and Poverty Point Archaeology: Essays in Honor of Clarence Hungerford Webb," edited by J. L. Gibson. Louisiana Archaeology 6:173-206.

Perttula, T. K.

2015 The Westerman Mound Site (41HO15), Houston County, Texas. Journal of Northeast Texas Archaeology 52:99-106.

Perttula, T. K., R. Cast, B. Gonzalez, and B. Nelson

2009 Documentation of Unassociated and Culturally Unidentifiable Funerary Objects in the U.S. Army Corps of Engineers, Fort Worth District Collections Housed at the Texas Archeological Research Laboratory at the University of Texas at Austin. Special Publication No. 13. Friends of Northeast Texas Archaeology, Pittsburg and Austin. 
Perttula, T. K., M. Tate, H. Neff, M. D. Glascock, E. Skokan, S. Mulholland, R. Rogers, and B. Nelson

1998 Analysis of the Titus Phase Mortuary Assemblage at the Mockingbird or "Kahbakayammaahin" Site (41TT550). Document No. 970849. Espey, Huston \& Associates, Inc., Austin.

Rolingson, M. A. and J. M. Howard

1997 Igneous Lithics of Central Arkansas: Identification, Sources, and Artifact Distribution. Southeastern Archaeology 16(1):33-50.

Schambach, F. F.

1982 An Outline of Fourche Maline Culture in Southwest Arkansas. In Arkansas Archeology in Review, edited by N. L. Trubowitz and M. D. Jeter, pp. 132-197. Research Series No. 15. Arkansas Archeological Survey, Fayetteville.

1998 Pre-Caddoan Cultures in the Trans-Mississippi South. Research Series 53. Arkansas Archeological Survey, Fayetteville.

2002 Fourche Maline: A Woodland Period Culture of the Trans-Mississippi South. In The Woodland Southeast, edited by D. G. Anderson and R. C. Mainfort, Jr., pp. 91-112. University of Alabama Press, Tuscaloosa.

Stephenson, R. L.

1948 Archeological Survey of McGee Bend Reservoir: A Preliminary Report. Bulletin of the Texas Archeological and Paleontological Society 19:57-73.

Story, D. A.

1990 Cultural History of the Native Americans. In The Archeology and Bioarcheology of the Gulf Coastal Plain, by D. A. Story, J. A Guy, B. A. Burnett, M. D. Freeman, J. C. Rose, D. G. Steele, B. W. Olive, and K. J. Reinhard, pp. 163-366. Research Series No. 38. 2 Vols. Arkansas Archeological Survey, Fayetteville.

Suhm, D. A. and E. B. Jelks (editors)

1962 Handbook of Texas Archeology: Type Descriptions. Special Publication No. 1, Texas Archeological Society, and Bulletin No. 4, Texas Memorial Museum, Austin. Reprinted in 2009, Gustav's Library, Davenport, Iowa.

Thomas, P. M., Jr., L. J. Campbell, and S. R. Ahler

1980 The Hanna Site: An Alto Village in Red River Parish. Louisiana Archaeology 5:1-381. 